\title{
Research on the Open Space in Urban Areas of Taiyuan
}

\author{
Panpan Wang ${ }^{1, a}$, Jing $\mathrm{Gao}^{2, \mathrm{~b}}$
}

Landscape Planning and Design, Department of Architecture and Civil Engineering, Taiyuan

University of Technology, Taiyuan, Shanxi, 030024, China

a526894855@qq.com, bjane2768@126.com

Keywords: Urban open space, Spatial distribution, Landscape ecology, Dynamic research, Sustainability.

\begin{abstract}
As essential part of a city's integrity, open space plays a key role in making complete urban functions, shaping a highly-accepted city image, creating a better urban environment and passing down historic and cultural heritage. Also, it is an important place where people contact and communicate with each other. The open space of a city is seen as the symbol and epitome of its dynamic development. This paper analyzes the developing processes of Taiyuan City in each period, and brings up useful advice for the future.
\end{abstract}

\section{Definition of urban open space}

The earliest definition appears in Metropolitan Open Space Act made in London in Britain in 1877. And then the 20th clause of the Open Space Act, amended in 1906, defined the open space as any enclosed or unenclosed land, on which there's no any form of buildings or less than $5 \%$ of which is occupied with buildings, and the rest of which is built into a part or other entertainment place, or is used to pile waste or is just unused. [1] Basically, there are two ways to interpret this concept: in narrow and general senses. Its general sense refers to the land and water areas of a city on all or most of which there is no artificial structure; the narrow sense means the public greens within a city. [2]

In general, the urban open space of a city includes city squares, neighborhood parks, small-sized parks, pocket parks and the outdoor space of campuses, elderly residential homes, child's nurseries and hospitals in a city. [3]

\section{Domestic and overseas research trends of open space}

The urban public space in western countries has gone through a rigorous, gradual and regular development history and eventually formed a complete theoretical system. Since it was brought up in 19 Century, open space was first thought highly in the field of urban planning. And then Geography, Science of Architectural Design, Science of Landscape Design, Landscape Ecology, Conservation Biology and other subjects as the development of its theoretical research and planning practice. Influenced by ecological theory and landscape ecological theory, ecological effects and functions have become a more important role in urban open space design. And the ecological determinism is developed from the theory that urban open space is the key in urban ecological system. But our country was a little behind the West in researching urban open space. Since the reform and opening up, we had been attaching our attention on economical construction and our city construction developed quickly while we ignored the historical context, cultural tradition, ideology, public service, living systems and other interior features that are of importance to city development. Only when stepping into 20th Century, we began to be aware of the urban open space's structure system, landscape ecology, low carbon and energy-saving, living systems, measurement functions, management of later stage, regional characteristics and users' experience as the idea of urban design was put forward.

As a typical inland developing city, the most part of the current research on its urban open space focuses on urban landscape color, plant species, and other public facilities while the research on the integrity of the urban open space is a little weak. Thus, this paper is about the development trend of Taiyuan Urban open space. 


\section{Developing processes of Taiyuan urban open space}

Taiyuan, with an old name of Jinyang and short name of Bing, is an ancient city with a history of 2,500 years. It went through an one-thousand-year revolution from Jinyang City in Tang Dynasty, Pingjin City and Taiyuan City in Song Dynasty and Taiyuan City in Ming Dynasty and Qing Dynasty (see the left part of Picture 1), and has been regarded as "Splendid Dragon City". This paper, based on the history of the Taiyuan's overall planning, studies the development trend of Taiyuan's urban open space in four stages: the traditional garden before 1949, the city park during 1950s and 1960s, the landscaping from the end of 1970 to the beginning of 1990s and the urban open space after 1990s.

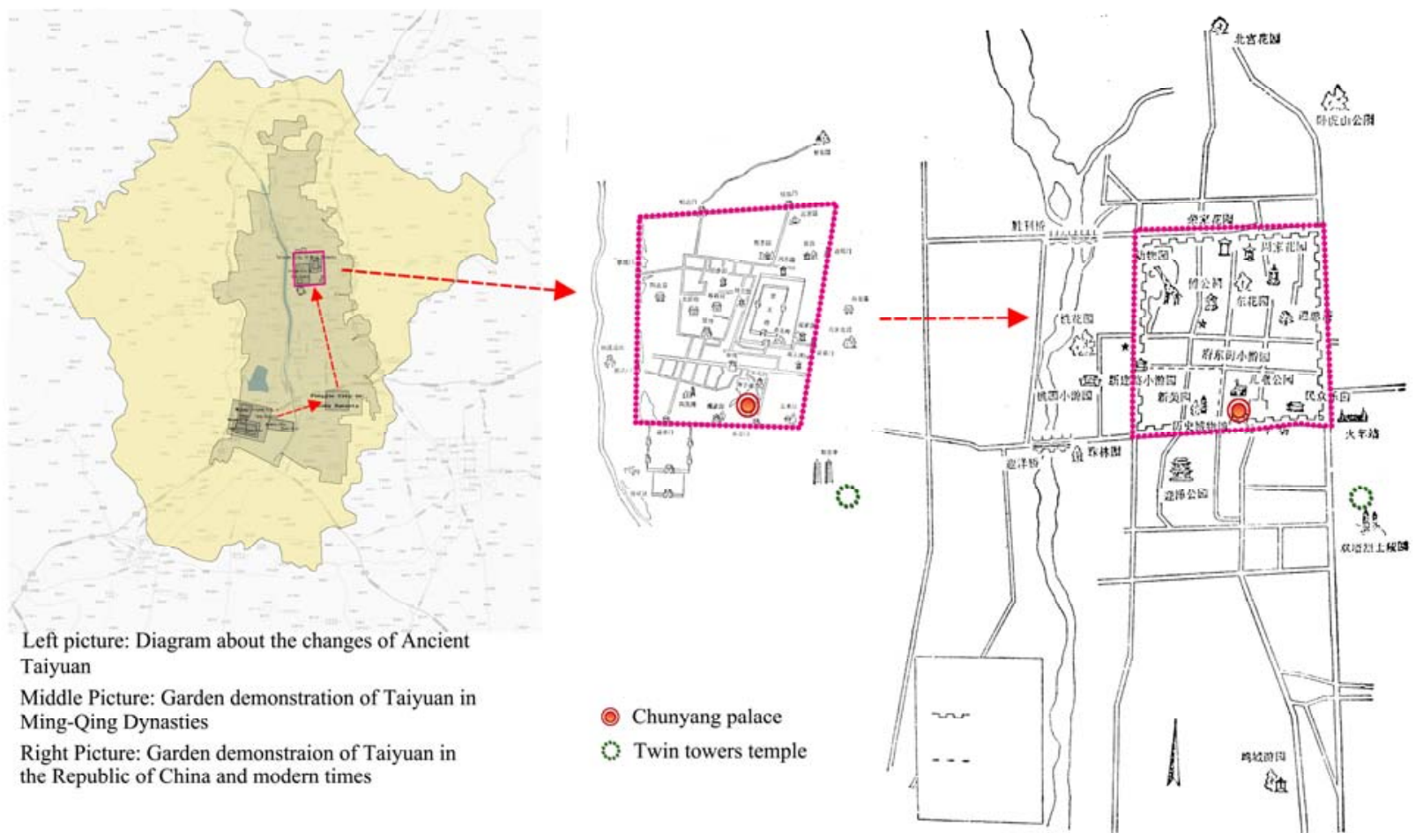

Fig.1 [4]

The traditional garden before 1949.Before the founding of new China, Taiyuan urban open space was developed on the basis of the traditional garden, mainly in the forms of temple garden, private garden and flower garden, which were usually enclosed family courtyards or the places used to entertain by high officials and rich men. At the end of Qing Dynasty, there were flower gardens in which trees and flowers were cultivated and traded and also the flower fairs began to come along. And the fact that people only could appreciate flowers in rich people's gardens was changed. So in some sense, the gardens in this period possessed the open and mass characters.

Ancient Jinyang City was moved to a new place where Taiyuan was building in Northern Song Dynasty. During that time, along the west band of Fen River, people built dams, planted willows, constructed pavilions, making it a ideal place of recreation and rest, with a beautiful name of "Liuxi" then. Through Song Dynasty and Yuan Dynasty, the East Mountain was covered with lush forest and the whole city was surrounded by scenic mountains and clear water. At the beginning of Ming Dynasty, the king of Jin started a building boom, expanding the city, constructing palaces and exploring gardens and finishing with the splendid palace complex-King of Jin's Palace and the huge-sized gardens of Xinghua Ridge and Songhua Slope. The mid of Ming Dynasty saw the appearance of many prince's gardens and private gardens, for which Taiyuan was known as the "Splendid Taiyuan City”. The majorities of gardens in Qing Dynasty were private gardens, of which the Retiring Garden, the Peach Garden, the Peace Garden and the Suns’ Villa were the most famous. During the later part of Qing Dynasty, there appeared flower fairs and flower gardens where plantlets and flowers were grown and traded (see the middle part of Fig.1). At the times of Republic of China, large number of high military and political officials in Shanxi began to purchase land and start construction to build residences and arrange gardens with little hills and nice ponds. From the 7th year to the 26th year of Republic of China (1918-1937), that's the period before China launched the 
Anti-Japanese War, residences and courtyards sprang up around Taiyuan, including some garden villas in Jinci. After the 1911 Revolution, in the city of Taiyuan, the first public garden-Wenying Garden was born (see the right part of Fig.1). [5]

Construction of City Parks during 1950s and 1960s . In the early years after China's liberation, Taiyuan urban open space is mainly in forms of city parks, flower gardens, petty street gardens and city squares, all of which enabled people to pursuit their spiritual demands as well as improved urban environment. However, the open space of this time was of incomplete in types and functions and not well managed. And the government set about to restore and expand city parks and build city parks, among which The People’s Park, which is called Wenying Park now, was the very first. Haizibian Park was the next. And during the four years between 1953 and 1957, the government built Yingze Park, Taiyuan Zoo and Wuyi Square Promenade Garden these three new ones and made a few alterations to the Jinci Park. After these projects, the open space was much improved in spatial proportion, road distribution, spatial hierarchy, ground cover, small landscapes and planting and became a unique space favoured by citizens.

Great leap forward in landscaping during the late 1970s and the mid of 1990s . The social life also changed from one single center of political life to multiple centers at this time, and consequently, city squares, an important reflection of social life, changed too. In the mid and late 1980s, our Architectural planning industry, influenced by the experience and achievements of other countries in urban planning and design, began to put focus on the planning and design of non-entity space. As the design stress of urban space, city squares are place where people reveal their modern life, communicate, entertain themselves and take rests, and thus, have great social and cultural significance.

The social life also changed from one single center of political life to multiple centers at this time, and consequently, city squares, an important reflection of social life, changed too. In the mid and late 1980s, our Architectural planning industry, influenced by the experience and achievements of other countries in urban planning and design, began to put focus on the planning and design of non-entity space. As the design stress of urban space, city squares are place where people reveal their modern life, communicate, entertain themselves and take rests, and thus, have great social and cultural significance.

Exploration of ecological open space after 1990s . At the end of 1990s, people became aware of the ecological landscape as the concept of sustainability sprang up. In the concept of ecological landscape, landscape is seen as a compound complex of human beings and nature and a organic, living and dynamic revolution process of environmental morphology. Ecological design concept has found itself in all parts of social life and we do our best to achieve a low-carbon, ecological and sustainable urban open space design. Take Fen River governance as the case study, at the very beginning, the purpose of governance was to discharge flood; now along the two bands of the river, there is waterfront landscape zones, restored urban wetlands and birds coming back, all of which provides people with an urban open space to have leisure and entertainment as well as discharges floods and beautifies the city and increases the species diversity. At this time urban open space has changed in types, morphology and functions: Multiplied open space types, such as city parks, city greens, city wetlands, specialized gardens, pedestrian streets, city squares, poly-scattered squares, waterfront space and so on. ; Diversified open space morphology, referring to all the city gardens and petty street gardens dotted along the waterfront landscape zones of Fen river as well as the planar ecological forests in the suburbs; Improved open space functions, creating a place for people to communicate, take rests and do entertainments, regulating urban microclimates and increasing the vitality of the city.

\section{Revolution of the urban open space around Taiyuan}

Diversified types. Before 1949, the most part of urban open space is private gardens, and then city parks and petty street gardens turned out. In the period of reform and opening up, with the development of the whole city, urban open space also developed rapidly, added with kinds of gardens, city greens, specialized gardens and city parks, to meet people's demands and enrich city space. At 
the end of 1990s, as the ecological idea became popular, wetland gardens, waterfront landscape zones and other green ecological open space were produced.

Multiple scales, complete functions. Traditional urban open space is mainly in the form of private gardens, with single function and limited measurements. The city development and construction demand that the measurements of open space should be decided according to its functions and target users. Proper measurements and rich functions generate sensory beauty. In the recent two decades, ecological idea and people's experience and feeling have become more important in the factors of urban open space. The purposes and functions of an open space are regarded to be the key to decide its measurements and users' viewing distance, field of vision and stay space, which provide users a perfect place to rest, view and entertain themselves.

Even distribution. At the early years of liberation, Taiyuan urban open space was mainly located in the downtown of the city. As the industry spread out to the outer parts, the open space has become even gradually in the nearest two decades. For the sake of users' accessibility, open space is of diversified morphology, including belt-distributed waterfront landscape zones along Fen River, variety of dotted city parks and petty street gardens and planar ecological forests in suburbs, forming an green system structure of "one circle, one axis, double districts, triple wedges, multiple galleries and gardens".

Updated ideas. Developing from the Geddes Patrick's research on the influence to a city brought by biology in the early times, the proposition of Ian Mcharg's "design with nature" to Richard Phillips Feynman's landscape ecology theory, urban landscape ecology has become the most acknowledged landscape cognitive model in modern times. Urban open space is supposed to be continuous, ecological and sustainable and has the functions of providing people with opportunities to have leisure, entertainment and cultural activities, increasing species diversity, benefiting education, healthy life, social and economical development, and eventually creating a high-quality environment.

People are the experiencing subject of urban open space, and in return, urban open space is designed to serve people, meet people's need of activities and build a comfortable space and environment. The facilities and equipment in open space should be provided on the first purpose of being in correspondence with people's need and the standard of humanization, as well as considering exterior beauty and sensory interest in the space.

\section{References}

[1] TOM T. Open Space Planning in London [M].Town Planning.1994.3.

[2] Zhang Hongou, Cen Qianhua, Research and development of urban open space in other countries

[J]. 78-84 of Urban Planning Forum, 2007(5).

[3] Carolyn Francis, Claire • Cooper • Marcus, Humanity place-Urban open space design guidelines (2nd version).

[4] The middle and right pictures from Taiyuan History. 1998.

[5] See Taiyuan History. 1998. 